\title{
A Rapid, Simple, Laboratory and Field-Adaptable DNA Extraction and Diagnostic Method Suitable for Insect-Transmitted Plant Pathogen and Insect Identification
}

\author{
Karolina Pusz-Bochenska, ${ }^{1,2,+}$ Edel Perez-Lopez, ${ }^{2}$ Tim J. Dumonceaux, ${ }^{1}$ Chrystel Olivier, ${ }^{1}$ and Tyler J. Wist ${ }^{1}$ \\ ${ }^{1}$ Agriculture and Agri-Food Canada, Saskatoon Research and Development Centre, Saskatoon, SK, Canada \\ ${ }^{2}$ University of Saskatchewan, Department of Biology, Saskatoon, SK, Canada
}

Accepted for publication 31 December 2019.

\begin{abstract}
Surveillance for insect-transmitted pathogens of plants involves sampling insects in the field, followed by transport of the samples to the laboratory for DNA extraction and molecular analysis. Sample transport and DNA extraction are time consuming and can delay the implementation of measures to mitigate the effects of insect-transmitted plant pathogens. Looking for a fast and reliable method to extract DNA in the field where insects were collected, we used Flinders Technology Associates PlantSaver cards, which are designed for plant DNA extraction. Insect DNA extraction can be achieved in the field, and extracted DNA can be amplified using the field-adaptable method, loop-mediated isothermal amplification (LAMP), in less than $1 \mathrm{~h}$. Additionally, we demonstrate the feasibility and accuracy of the paper extraction method for molecular identification to the species level using mitochondrial cytochrome oxidase 1 amplification and sequencing on 11 genera of insects
\end{abstract}

Aster yellows (AY)-associated diseases are caused by phytoplasmas belonging to the group $16 \mathrm{SrI}$ and the species 'Candidatus Phytoplasma asteris' (Lee et al. 2004). In North America, AY is transmitted primarily by the migratory aster leafhopper, Macrosteles quadrilineatus Forbes (Hemiptera: Cicadellidae) (Chiykowski 1981; Kunkel 1926). Depending on their number and infectivity, aster leafhoppers can cause AY outbreaks and severe production losses in many crops, such as barley, oats, and canola (Hollingsworth et al. 2008; Martini et al. 2018; Olivier et al. 2017). Integrated management of phytoplasma diseases can be achieved when the number and level of infectivity of the insect vectors is known, allowing growers to decide if insecticidal control is warranted (Bianco et al. 2019). This type of integrated pest management requires a rapid turnaround of field-collected insect samples and molecular diagnostic tests to facilitate the management decision process. Therefore, it is imperative that once the first migratory aster leafhoppers have been detected, rapid collection and testing of the

${ }^{\dagger}$ Corresponding author: K. Pusz-Bochenska; k.pusz@usask.ca

Funding: This work was supported by Agriculture and Agri-Food Canada A-base project 1668 - Sustainable small fruit production to T.D. and a WGRF-funded project on aster yellows to T.W.

The author(s) declare no conflict of interest.

(C) Her Majesty the Queen in Right of Canada, as represented by Agriculture and Agri-Food Canada (AAFC), 2020.

\section{Abstract}

including beetles, leafhoppers, flies, psyllids, and aphids. The method was suitable for insects collected using three common methods: live-trapped and frozen, stored in ethanol, or trapped on sticky cards. Moreover, by testing leafhoppers collected in 2018 in the field, we demonstrated that the LAMP assay using the chaperonin- 60 target detects a higher proportion of samples positive for 'Candidatus Phytoplasma asteris' than conventional PCR targeting 16S rRNA. Lastly, the paper extraction method was used to determine the prevalence of leafhoppers carrying the plant pathogenic bacterium ' $\mathrm{C}$. $\mathrm{P}$. asteris', which causes aster yellows from a laboratory-reared colony using PCR-based tests (conventional PCR, $\mathrm{PPCR}$, and droplet digital PCR) and the nonPCR-based LAMP assay.

Keywords: cytochrome oxidase 1, DNA extraction, insects, LAMP, aster yellows phytoplasma, Macrosteles quadrilineatus

leafhoppers occurs to immediately evaluate the outbreak risk by confirming the presence of the AY phytoplasma, the number of leafhoppers, and the percentage of the leafhopper population harboring the AY phytoplasma.

Phytoplasmas are typically detected using molecular diagnostic methods such as conventional polymerase chain reaction (PCR) and quantitative PCR (qPCR), which can offer relatively rapid results. Although these methods are highly sensitive and specific, they typically require equipment that is not readily available outside of a laboratory environment. Loop-mediated isothermal amplification (LAMP) is an alternative molecular diagnostic method that is sensitive and specific (Pérez-López et al. 2017). The LAMP technique has the additional benefit of being adaptable to a laboratory-independent environment (Bühlmann et al. 2013; Harper et al. 2010; Keremane et al. 2015), allowing the detection of particular sequences within DNA samples in as little as $10 \mathrm{~min}$ without the need for thermal cycling. However, field-based DNA amplification requires a technique for DNA extraction from insects and their transmitted pathogens that can be achieved outside of the laboratory.

Here, we describe a method to extract DNA from field-collected insects using Flinders Technology Associates (FTA) PlantSaver cards that can be accomplished in less than $30 \mathrm{~min}$ in a field setting. We demonstrate the suitability of the extracted DNA as a template for PCR targeting the mitochondrial cytochrome oxidase 1 (CO1) barcoding gene (Hebert et al. 2003) by amplifying field-collected insects belonging to different species, previously identified using morphological 
characteristics. Further, we demonstrate the effectivenessof the paper-based DNA extraction method to detect the presence of phytoplasma in field-collected aster leafhoppers using LAMP by comparing results obtained using the LAMP assays with those obtained using standard PCR tests. We determined the efficiency of this technique by comparing DNA yield extracted from laboratory-reared, AY-infected M. quadrilineatus using conventional laboratory methods of DNA extraction and FTA cards. We also reveal that the FTA card-obtained DNA can be used as a template for nested PCR targeting the 16S rRNA and ribosomal protein $(r p)$ gene operon, as well as LAMP assays targeting the chaperonin-60 gene (cpn60), to detect the presence of AY phytoplasma in laboratory-reared $M$. quadrilineatus. Finally, the correlation among the techniques is discussed.

\section{Insect DNA Extraction Using FTA Cards and Insect Molecular Identification}

FTA cards have previously been demonstrated as a suitable means of preserving insect samples for DNA extraction, although inconsistencies in amplification efficiencies have been reported (Bujang et al. 2011; Dickey et al. 2012). For this reason, Dickey et al. (2012) evaluated the effect of DNA elution protocols on the amplification efficiency of DNA extracted from silver leaf (sweet potato) whiteflies, Bemisia tabaci (Hemiptera: Aleyrodidae). This protocol involved elution and subsequent cleaning with a commercial kit, resulting in an eluted volume of $\sim 600 \mu$ l that was then concentrated under vacuum. Because these steps are not amenable to application outside of a laboratory setting, we evaluated the possibility of using a more straightforward elution protocol involving heating the disk containing the crushed insect DNA in an elution buffer for $20 \mathrm{~min}$ to generate insect and entomogenous bacterial DNA suitable for amplification.

Insects were placed on an FTA plant card (Whatman, Mississauga, ON, Canada), the cover sheet closed, and the samples homogenized with several blows from a standard-size rubber mallet. Samples were air-dried for $\sim 60 \mathrm{~min}$ or heat-dried using a 120V/1,500W hair dryer for $2 \mathrm{~min}$. The dried homogenate was excised from the paper matrix using a hole puncher with a diameter ranging from 1.2 to $5 \mathrm{~mm}$ (depending on the size of the insects being crushed) and the paper disk transferred to a $1.5-\mathrm{ml}$ microfuge tube. A volume of $200 \mu \mathrm{l}$ of lysis buffer (AP1 lysis buffer from DNeasy Plant Mini Kit, Qiagen) was added, and the tubes were incubated for $2 \mathrm{~min}$ at ambient temperature. This last step was repeated once, and the disks were then washed twice using $200 \mu \mathrm{l}$ of TE $0.1 \times$ buffer $(10 \mathrm{mM}$ Tris- $\mathrm{HCl}$, $0.1 \mathrm{mM}$ EDTA). To facilitate drying, paper disks were rinsed once with $200 \mu \mathrm{l}$ of $70 \%$ ethanol and air-dried for $5 \mathrm{~min}$ with the tube lid open. For elution of the DNA from the disk, 20 to $200 \mu$ l of TE $0.1 \times$ buffer was added and the disk incubated at $90^{\circ} \mathrm{C}$ for $20 \mathrm{~min}$. Condensate was recovered by briefly centrifuging the tubes (also compatible with shaking the tubes if a centrifuge is not available), and then the liquid fraction was transferred to a fresh tube, or the disk removed using forceps, making sure to remove as much of the liquid from the paper as possible.

Aster leafhoppers and several other insects were collected with yellow sticky card traps (Alpha Scents, West Linn, OR) or with sweep nets in canola and wheat crops grown near Saskatoon (Saskatchewan, Canada) between May and August 2018. In the same season, tree-infesting beetles were collected in Lindgren funnel traps baited with elm bark beetle pheromone and hostvolatile lures (ChemTica Internacional, S. A.). The beetles were then freeze-killed and stored either at $-18^{\circ} \mathrm{C}$ or in $70 \%$ ethanol. DNA extraction was performed on individual insects using the FTA card (as above) on 64 field-collected specimens to be tested for species identification. Extracted DNA was used as a template for PCR with universal primers targeting the mitochondrial CO1 gene (Hebert et al. 2003). Amplicons were purified using QiaQuick columns (Qiagen, Toronto, ON, Canada) and sequenced using the amplification primers (Eurofins Genomics, Toronto, ON, Canada). Insects were identified by comparing their $\mathrm{CO} 1$ amplicon sequence to the Barcode of Life database (Ratnasingham and Hebert 2007, 2013) and/or comparison with GenBank using the Basic Local Alignment Search Tool (BLAST) (Altschul et al. 1990). All sequences were deposited to GenBank (accession numbers provided in Table 1).

The DNA was readily amplifiable by PCR targeting CO1 (Fig. 1A), although some samples required dilution of the $20 \mu$ l of extract for PCR product generation (Table 1), and the CO1 identifications were consistent with the presumptive identity of the insects determined by visual examination. The extraction of individuals of different species including beetles (Coleoptera: Scolytidae), leafhoppers (Hemiptera: Cicadellidae), aphids (Hemiptera: Aphididae), flies (Diptera: Muscidae and Chironomidae), parasitic wasps (Hymenoptera: Braconidae), and psyllids (Homoptera: Psyllidae) yielded 2 to $200 \mathrm{ng}$ of DNA in a volume of $20 \mu \mathrm{l}$ (Table 1). This extraction method also provided DNA suitable for amplification by the LAMP assay targeting phytoplasmas. The LAMP assay, following conditions previously described by Pérez-López et al. (2017), detected the presence of ' $\mathrm{Ca}$. P. asteris' in $\mathrm{M}$. quadrilineatus, the known AY vector species (Fig. 1B and C).

\section{'Ca. P. asteris' Detection Using DNA Extracted with FTA Cards as a Template for Molecular Diagnostic Assays}

Phytoplasma detection is typically undertaken in the laboratory using a nested PCR strategy targeting the 16S rRNA-encoding gene (Gundersen and Lee 1996) or the $r p$ operon (Martini et al. 2007). Although these methods are relatively sensitive and specific, they are time consuming (up to 7 to $8 \mathrm{~h}$ for the two sequential PCRs and gel analysis) and not easily suited to application outside of the laboratory. Therefore, we compared the performance of the nested PCR and LAMP assays on field-collected insects. DNA from 356 aster leafhoppers collected in fields from Saskatchewan, Canada, were individually extracted using FTA cards and were used for nested PCR targeting the 16S rRNA-encoding gene and LAMP assay targeting cpn60 (Table 2).

Of the 356 aster leafhoppers, two insect specimens tested positive for the presence of the AY phytoplasma using the nested PCR technique targeting 16S rRNA, whereas 12 insect specimens showed the presence of AY phytoplasma DNA using the LAMP assay targeting the cpn60 gene (Table 2). The nested PCR and LAMP assays were concordant on 342 samples that tested negative, corresponding to a test specificity (Banoo et al. 2006) of $97 \%$ for LAMP compared with 16S rRNA nested PCR. Due to the low number of positive samples observed using both methods, it was impossible to compare the assays on positives. The 10 samples that tested positive by LAMP but negative by nested PCR suggested that the LAMP assay may feature improved sensitivity compared with nested PCR. This result is consistent with previous results suggesting that LAMP has a higher analytical sensitivity compared with PCR and is better able to detect phytoplasmas in infected plant tissues (Pérez-López et al. 2017).

\section{'Ca. P. asteris' Detection in Laboratory-Reared Insects Using PCR-Based Tests and LAMP Assay}

To evaluate the performance of the FTA card-based DNA extraction using phytoplasma-positive samples, we used insects from a captive $M$. quadrilineatus colony that is continuously fed phytoplasmainfected periwinkle, as described by Bahar et al. (2018). 
Insect DNA extracted using the FTA cards was used as a template for a nested PCR targeting the 16S rRNA-encoding gene (Gundersen and Lee 1996; Lee et al. 1998). Additionally, each sample was analyzed using a nested PCR targeting the $r p$ operon (rpPCR) (Gundersen et al. 1996). Positive results were scored by the appearance of an amplicon of $\sim 1.2 \mathrm{~kb}$ by agarose gel electrophoresis. Finally, the extracts were also used as a template for realtime qPCR (Olivier et al. 2017), droplet digital PCR (ddPCR) (Olivier et al. 2017), and LAMP (Hammond et al. in preparation; Pérez-López et al. 2017) assays targeting the cpn60 (Dumonceaux et al. 2014) gene of ' $\mathrm{Ca}$. P. asteris'.

Pairing FTA card DNA extraction with LAMP, a fully fieldamenable protocol, returned results that were not significantly different than qPCR, nested PCR targeting 16S rRNA, or rpPCR (generalized linear model, Poisson distribution, $\chi^{2}=3.89$, $\mathrm{df}=3$, $P=0.273$ ) (Table 3). Of the 25 aster leafhoppers sampled in the AYinfected colonies, 21 were positive for the presence of AY phytoplasma by LAMP targeting cpn60, whereas 11 and 19 were positive using nested PCR targeting $16 \mathrm{~S}$ rRNA and the $r p$ gene, respectively
(Table 3). The AY phytoplasma load was quantified in each sample using ddPCR, and the results of each assay were compared on the basis of the phytoplasma cpn60 copies (same as genome copies) per insect (Table 3). This result showed that most of the samples that gave discordant results among the diagnostic methods had lower levels of AY phytoplasma; for example, all samples with a measured phytoplasma load above 7,762 copies/insect were concordant among all methods (Table 3). All samples with a phytoplasma load below this tested negative using $16 \mathrm{~S}$ nested PCR, whereas LAMP and real-time qPCR displayed perfect concordance and were positive on all samples that carried $>1,000$ phytoplasma genomes per insect (Table 3). The rpPCR gave less reliable results, testing negative on some samples with higher phytoplasma loads and positive on some of the samples with the lowest phytoplasma loads (Table 3). These results are typically observed when operating near the assay limit of detection (Smieja et al. 2001) and suggest that LAMP, rpPCR, and qPCR have lower limits of detection compared with $16 \mathrm{~S}$ nested PCR. Indeed, almost 10,000 copies of ' $\mathrm{Ca}$. P. asteris' were necessary for detection using $16 \mathrm{~S}$ nested PCR, whereas approximately

\begin{tabular}{|c|c|c|c|c|c|c|c|c|c|c|}
\hline \multirow[b]{4}{*}{ Sample ID } & \multirow{4}{*}{$\begin{array}{l}\text { Insect origin } \\
\text { and treatment }\end{array}$} & \multirow{2}{*}{\multicolumn{2}{|c|}{ CO1 amplification ${ }^{a}$}} & $\begin{array}{c}\text { TABLE } 1 \\
\text { ntification of insects by } \\
\text { f Life database (BOLD) }\end{array}$ & inas & no & ch & $\begin{array}{c}0 x \\
00\end{array}$ & 1 & 1) and \\
\hline & & & & \multirow[b]{3}{*}{ BOLD ID (>99\%) } & \multirow{3}{*}{$\begin{array}{l}\text { No. of } \\
\text { samples }\end{array}$} & \multirow{2}{*}{\multicolumn{2}{|c|}{$[D N A], n g / \mu l^{b}$}} & \multirow{2}{*}{\multicolumn{2}{|c|}{ DNA yield (ng) }} & \multirow{3}{*}{$\begin{array}{l}\text { GenBank } \\
\text { no. }\end{array}$} \\
\hline & & \multirow[b]{2}{*}{ Undiluted } & \multirow{2}{*}{$\begin{array}{c}1: 10 \\
\text { dilution }\end{array}$} & & & & & & & \\
\hline & & & & & & Mean & SEM & Mean & SEM & \\
\hline AB160420-1 & Live caught & ++ & NT & $\begin{array}{l}\text { Hylesinus criddlei } \\
\text { (Coleoptera: Scolytidae) }\end{array}$ & 1 & 5.2 & & 104.4 & & MF958480 \\
\hline ABB-7D & Sticky card & NT & ++ & $\begin{array}{l}\text { Hylesinus aculeatus } \\
\text { (Coleoptera: Scolytidae) }\end{array}$ & 1 & 1.17 & & 23.4 & & MF958482 \\
\hline EGA-5A & Live caught & + & NT & $\begin{array}{l}\text { Sitobion avenae } \\
\text { (Hemiptera: Aphididae) }\end{array}$ & 8 & 5.5 & 1.3 & 110.8 & 26.0 & MF958486 \\
\hline $\begin{array}{l}\text { EGA70\% } \\
\text { ETOH-5A }\end{array}$ & Ethanol & ++ & NT & $\begin{array}{l}\text { Sitobion avenae } \\
\text { (Hemiptera: Aphididae) }\end{array}$ & 8 & 1.7 & 1.0 & 33.6 & 19.1 & MF958487 \\
\hline $\begin{array}{l}\text { ВСO70\% } \\
\text { ЕTOH-1A }\end{array}$ & Ethanol & + & ++ & $\begin{array}{l}\text { Rhopalosiphum padi } \\
\text { (Hemiptera: Aphididae) }\end{array}$ & 4 & 0.9 & 0.5 & 18.2 & 9.6 & MF958485 \\
\hline BCO-5A & Live caught & + & ++ & $\begin{array}{l}\text { Aphidius colemani } \\
\text { (Hymenoptera: } \\
\text { Braconidae) }\end{array}$ & 1 & 0.4 & & 8.7 & & MF958484 \\
\hline $\begin{array}{l}\text { GP70\% } \\
\text { ETOH-5A }\end{array}$ & Ethanol & - & ++ & $\begin{array}{l}\text { Schizaphis graminum } \\
\text { (Hemiptera: Aphididae) }\end{array}$ & 5 & 0.2 & 0.0 & 3.7 & 0.8 & MF958479 \\
\hline MQ-2A & Live caught & ++ & ++ & $\begin{array}{r}\text { Macrosteles quadrilineatus } \\
\text { (Hemiptera: Cicadellidae) }\end{array}$ & 8 & 1.9 & 0.7 & 38.9 & 15.0 & MF958488 \\
\hline $\begin{array}{l}\text { MQ70\% } \\
\text { ETOH-1A }\end{array}$ & Ethanol & ++ & NT & $\begin{array}{r}\text { Macrosteles quadrilineatus } \\
\text { (Hemiptera: Cicadellidae) }\end{array}$ & 8 & 0.8 & 0.4 & 15.6 & 7.3 & MF958489 \\
\hline SC beetle 1 & Sticky card & - & + & $\begin{array}{l}\text { Scolytus schevyrewi } \\
\text { (Coleoptera: Scolytidae) }\end{array}$ & 1 & 5.4 & & 108.8 & & MF958491 \\
\hline NS-hopper & Ethanol & ++ & NT & $\begin{array}{l}\text { Penthimia americana } \\
\text { (Hemiptera: Cicadellidae) }\end{array}$ & 1 & 1.6 & & 32.0 & & MF958490 \\
\hline
\end{tabular}

${ }^{\text {a }} \mathrm{CO} 1$ band intensity upon agarose gel electrophoresis: + = faint band; ++ = intense band; $-=$ no amplification observed; and NT = not tested.

${ }^{b}$ Reported as mean DNA concentration and yield \pm standard error of the mean (SEM) when multiple samples were examined. 
1,000 copies could be detected using the other methods. Apparent analytical sensitivity is therefore improved by an order of magnitude using rpPCR, qPCR, and LAMP versus $16 \mathrm{~S}$ nested PCR (Table 3). Although we were able to identify a significant, inverse correlation between the LAMP time to positive and the number of phytoplasma genomes (Spearman $\rho=-0.846, P<0.001$ ), this relationship was not suitable for predicting the number of genomes in an unknown sample. Therefore, although the time to positive provides a quantitative estimate, we have implemented the assay as a binomial (positive/ negative), semiquantitative method.

\section{Conclusion}

Although LAMP is a useful tool for testing insects for the presence of ' $\mathrm{Ca}$. P. asteris', field detection would be improved if preceded by a rapid and field-deployable DNA extraction technique that can be easily and routinely used by end users (growers, producers) (Keremane et al. 2015). DNA extraction from insects is commonly performed using complex, laboratory-based methods that use chemical lysis, centrifugation, and ethanol precipitation to yield amplifiable DNA (Murray and Thompson 1980; Pérez-López et al. 2016, 2017; Tanne et al. 2001). Moreover, samples must be brought from the field where they are captured to the laboratory for analysis, potentially adding days or weeks to analysis time. Methods such as LAMP can detect pathogens harbored by the insects rapidly in a field environment (Harper et al. 2010). To

\section{TABLE 2}

Comparison of two methods of 'Candidatus Phytoplasma

asteris' detection in Macrosteles quadrilineatus collected in

Saskatchewan in $\mathbf{2 0 1 8}$ and test sensitivity and specificity

\section{5 rRNA nested PCR}

\begin{tabular}{lccc}
\cline { 2 - 3 } LAMP & Positive & Negative & Total \\
Positive & 2 & 10 & 12 \\
Negative & 0 & 344 & 344 \\
Total & 2 & 354 & 356
\end{tabular}

Test sensitivity $\quad 1.00$

$\begin{array}{lll}\text { Test specificity } & \ldots & 0.97\end{array}$
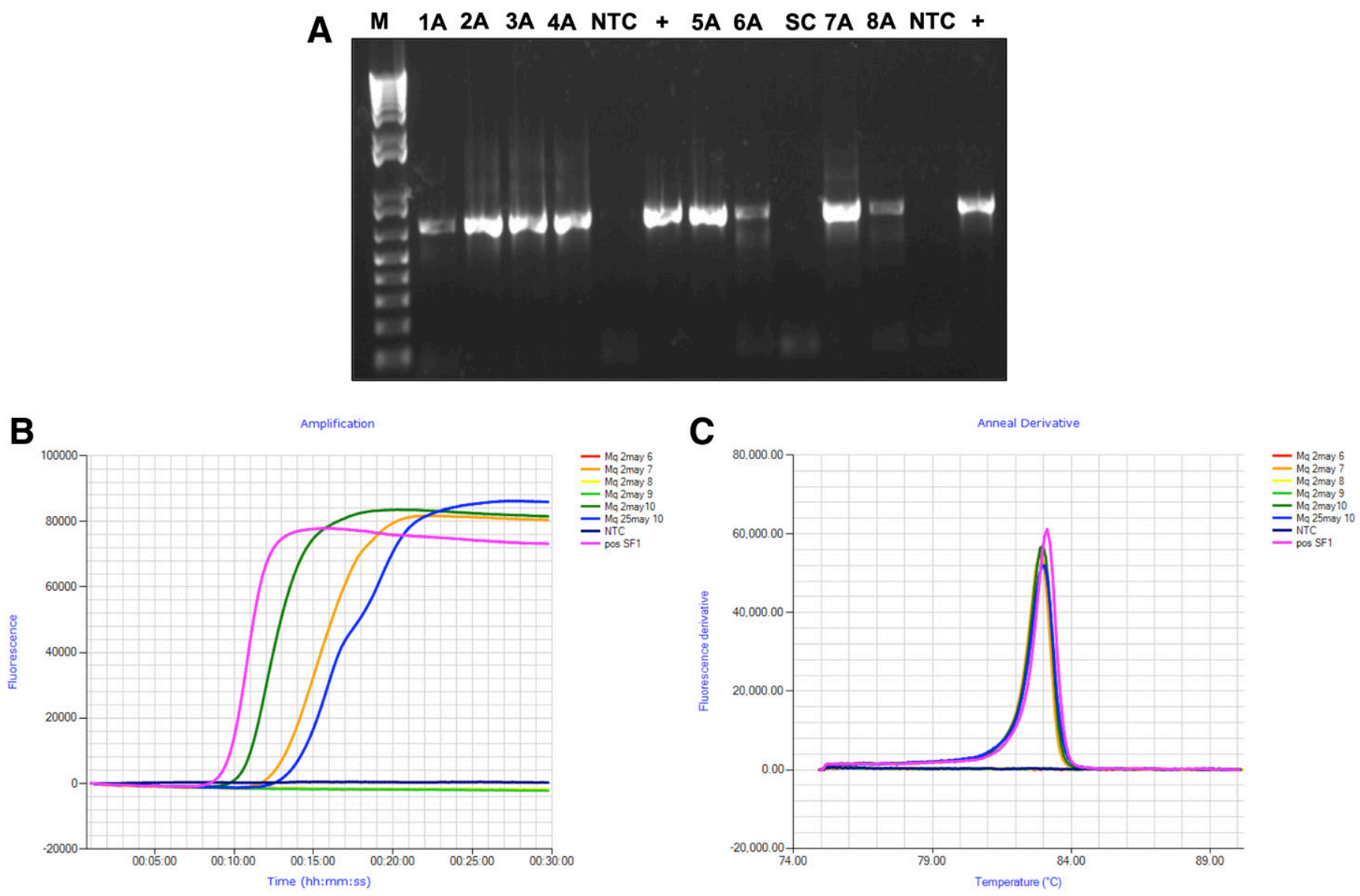

\section{FIGURE 1}

Amplification of DNA extracted from insects using the paper-based method. A, PCR amplification of CO1 gene from samples EGA 1 to 8 (Sitobion avenae, see Table 1). In the amplification two controls were included, no template control (NTC), and a reaction using template DNA from canola plants as a specificity control (SC). In the first NTC the faint band observed is from loading error/spillover from adjacent lanes. B, Detection of 'Candidatus Phytoplasma asteris' (aster yellows; phytoplasma group 16Srl) in leafhoppers (Macrosteles quadrilineatus) extracted using the paper-based method described herein. Of the six insects tested, three were positive for the plant-pathogenic bacterium. These results were confirmed using the DNA samples as a template for PCR assays with universal PCR primers previously described for phytoplasmas (Dumonceaux et al. 2014). C, Annealing curves of the loop-mediated isothermal amplification (LAMP) products produced in B, demonstrating that the correct LAMP product was generated from the positive insects. Amplification and annealing curves were generated using Isothermal Mastermix and a Genie instrument (Optigene, U.K.). 
TABLE 3

Results of screening specimens of Macrosteles quadrilineatus originating from non-AY-infected and AY-infected laboratory colonies, for the presence of AY phytoplasma (AY-P) using paper-extracted DNA

\begin{tabular}{|c|c|c|c|c|c|c|}
\hline \multirow[b]{3}{*}{ Sample } & \multirow{2}{*}{\multicolumn{2}{|c|}{ AY-P LAMP }} & \multicolumn{2}{|c|}{ Phytoplasma nested PCR } & \multirow{3}{*}{$\begin{array}{l}\text { AY-P } \mathbf{q P C R} \\
\text { result }\end{array}$} & \multirow{3}{*}{$\begin{array}{c}\text { AY-P ddPCR } \\
\text { copies/insect-log10 }\end{array}$} \\
\hline & & & \multirow{2}{*}{$\begin{array}{l}\text { Targeting } 165 \\
\text { rRNA result }\end{array}$} & \multirow{2}{*}{$\begin{array}{c}\text { Targeting ribosomal } \\
\text { protein result }\end{array}$} & & \\
\hline & Result & $\mathbf{T}_{\mathrm{p}}, \mathrm{min}$ & & & & \\
\hline Mq2may8 & $\mathrm{Neg}$ & 0 & $\mathrm{Neg}$ & $\mathrm{Neg}$ & $\mathrm{Neg}$ & 2.26 \\
\hline Mq2may9 & $\mathrm{Neg}$ & 0 & $\mathrm{Neg}$ & $\mathrm{Neg}$ & $\mathrm{Neg}$ & 2.28 \\
\hline Mq2may6 & Neg & 0 & $\mathrm{Neg}$ & $\mathrm{Neg}$ & $\mathrm{Neg}$ & 2.94 \\
\hline Mq25may 10 & Pos & 13.75 & $\mathrm{Neg}$ & Neg & Pos & 3.28 \\
\hline Mq25may5 & Pos & 15.50 & $\mathrm{Neg}$ & Pos & Pos & 3.32 \\
\hline Mq25may6 & Pos & 14.25 & $\mathrm{Neg}$ & Pos & Pos & 3.38 \\
\hline Mq25may3 & Pos & 14.25 & $\mathrm{Neg}$ & Pos & Pos & 3.38 \\
\hline Mq25may8 & Pos & 13.50 & $\mathrm{Neg}$ & Pos & Pos & 3.40 \\
\hline Mq2may7 & Pos & 14.75 & Pos & Pos & Pos & 4.46 \\
\hline Mq2may1 & Pos & 13.00 & Pos & Pos & Pos & 4.67 \\
\hline Mq2may3 & Pos & 12.25 & Pos & Pos & Pos & 4.73 \\
\hline Mq2may 10 & Pos & 11.75 & Pos & Pos & Pos & 5.41 \\
\hline $\mathrm{Mq} 14 \mathrm{M}$ & Pos & 11.00 & Pos & Pos & Pos & 5.48 \\
\hline Mq3M & Pos & 11.00 & Pos & Pos & Pos & 5.48 \\
\hline $\mathrm{Mq} 12 \mathrm{M}$ & Pos & 10.30 & Pos & Pos & Pos & 5.80 \\
\hline Mq5M & Pos & 10.30 & Pos & Pos & Pos & 5.90 \\
\hline $\mathrm{Mq} 21 \mathrm{M}$ & Pos & 9.31 & Pos & Pos & Pos & 6.16 \\
\hline $23 \mathrm{M}$ & Pos & 9.36 & Pos & Pos & Pos & 6.28 \\
\hline
\end{tabular}

${ }^{\text {a }} \mathrm{AY}=$ aster yellows; LAMP = loop-mediated isothermal amplification; $\mathrm{qPCR}$ = quantitative real time PCR; and ddPCR = droplet digital PCR.

maximize the utility of LAMP, a laboratory-independent means of extracting DNA from insects is required. Application of the FTA matrix card, which is designed for the preservation of plant tissues for DNA extraction, to insect samples with a modified washing and elution protocol facilitated the extraction of amplifiable DNA from an array of insect families. Importantly, the paper-based DNA extraction method enabled the detection of AY phytoplasmas harbored by aster leafhoppers. When coupled with LAMP detection, insects harboring lower levels of phytoplasma could be detected compared with nested PCR assays, meaning that actionable results on field-collected insects can be obtained earlier in the season, possibly before the bacteria have accumulated in the insects to levels sufficient for transmission. In our experiments, the total assay time from insect capture to the determination of positivity with LAMP ranged from $30 \mathrm{~min}$ to $2 \mathrm{~h}$, whereas the standard DNA extraction and nested PCR technique took up to 1 week to complete. Moreover, the entire procedure can be completed with minimal steps and without the need for extensive laboratory equipment. The portable, field-adapted technique significantly increased the speed with which results can be obtained from field-collected insects.

This study demonstrates that the insect paper-based DNA extraction method using FTA cards is fast and easy to operate. The fact that this is a cross-species, universal method of entomopathogen diagnostics affirms its potential as a field diagnostic tool for multiple diagnostic tests. This field-adaptable technique of DNA extraction works for insects of different species collected using a variety of methods, and, coupled with the LAMP assay for pathogen detection, the method theoretically can be applied to develop assays that could detect any insect-transmitted pathogen under field conditions.

\section{Acknowledgments}

The authors thank Rodney Burghardt of the City of Saskatoon Pest Management Department for collection of bark beetles.

\section{Statement of Data Availability}

CO1 sequences have been deposited to GenBank, with accession numbers provided in Table 1.

\section{Literature Cited}

Altschul, S. F., Gish, W., Miller, W., Myers, E. W., and Lipman, D. J. 1990. Basic local alignment search tool. J. Mol. Biol. 215:403-410.

Bahar, M. H., Wist, T. J., Bekkaoui, D. R., Hegedus, D. D., and Olivier, C. Y. 2018. Aster leafhopper survival and reproduction, and aster yellows transmission under static and fluctuating temperatures, using ddPCR for phytoplasma quantification. Sci. Rep. 8:227.

Banoo, S., Bell, D., Bossuyt, P., Herring, A., Mabey, D., Poole, F., Smith, P. G., Sriram, N., Wongsrichanalai, C., Linke, R., O'Brien, R., Perkins, M., Cunningham, J., Matsoso, P., Nathanson, C. M., Olliaro, P., Peeling, R. W., and Ramsay, A. 2006. Evaluation of diagnostic tests for infectious diseases: General principles. Nat. Rev. Microbiol. 4:S20-S32. 
Bianco, P. A., Romanazzi, G., Mori, N., Myrie, W., and Bertaccini, A. 2019. Integrated management of phytoplasma diseases. Pages 237-258 in: Phytoplasmas: Plant Pathogenic Bacteria - II: Transmission and Management of Phytoplasma-Associated Diseases. A. Bertaccini, P. G. Weintraub, G. P. Rao, and N. Mori, eds. Springer, Singapore.

Bühlmann, A., Pothier, J. F., Rezzonico, F., Smits, T. H. M., Andreou, M., Boonham, N., Duffy, B., and Frey, J. E. 2013. Erwinia amylovora loopmediated isothermal amplification (LAMP) assay for rapid pathogen detection and on-site diagnosis of fire blight. J. Microbiol. Methods 92:332-339.

Bujang, N. S., Harrison, N. A., and Su, N.-Y. 2011. An improved method for extraction and purification of termite endo- $\beta$-1,4-glucanase from FTA ${ }^{\circledR}$ cards. Fla. Entomol. 94:356-358.

Chiykowski, L. 1981. Epidemiology of diseases caused by leafhopper-borne pathogens. Pages 106-159 in: Plant Disease and Vectors. K. Maramorosch and K. Harris, eds. Academic Press, New York, NY.

Dickey, A. M., Shatters, R. G., and McKenzie, C. L. 2012. A comparison of two methods of eluting insect DNA from Flinders Technology Associates cards. Fla. Entomol. 95:790-793.

Dumonceaux, T. J., Green, M., Hammond, C., Perez, E., and Olivier, C. 2014. Molecular diagnostic tools for detection and differentiation of phytoplasmas based on chaperonin-60 reveal differences in host plant infection patterns. PLoS One 9:e116039.

Gundersen, D., and Lee, I. M. 1996. Ultrasensitive detection of phytoplasmas by nested-PCR assays using two universal primer pairs. Phytopathol. Mediterr. 35:144-151.

Gundersen, D. E., Lee, I. M., Schaff, D. A., Harrison, N. A., Chang, C. J., Davis, R. E., and Kingsbury, D. T. 1996. Genomic diversity and differentiation among phytoplasma strains in 16S rRNA groups I (aster yellows and related phytoplasmas) and III (X-disease and related phytoplasmas). Int. J. Syst. Bacteriol. 46:64-75.

Harper, S. J., Ward, L. I., and Clover, G. R. 2010. Development of LAMP and real-time PCR methods for the rapid detection of Xylella fastidiosa for quarantine and field applications. Phytopathology 100:1282-1288.

Hebert, P. D. N., Cywinska, A., Ball, S. L., and deWaard, J. R. 2003. Biological identifications through DNA barcodes. Proc. R. Soc. Lond. B Biol. Sci. 270: 313-321.

Hollingsworth, C., Atkinson, L., Samac, D., Larsen, J., Motteberg, C., Abrahamson, M., Glogoza, P., and MacRae, I. 2008. Region and field level distributions of aster yellows phytoplasma in small grain crops. Plant Dis. 92:623-630.

Keremane, M. L., Ramadugu, C., Rodriguez, E., Kubota, R., Shibata, S., Hall, D. G., Roose, M. L., Jenkins, D., and Lee, R. F. 2015. A rapid field detection system for citrus huanglongbing associated 'Candidatus Liberibacter asiaticus' from the psyllid vector, Diaphorina citri Kuwayama and its implications in disease management. Crop Prot. 68:41-48.

Kunkel, L. 1926. Studies on aster yellows. Am. J. Bot. 13:646-705.
Lee, I. M., Davis, D. E., Bottner, R. E., Gundersen-Rindal, K. D., Marcone, C., and Seemüller, E. 2004. 'Candidatus Phytoplasma asteris', a novel phytoplasma taxon associated with aster yellows and related diseases. Int. J. Syst. Evol. Microbiol. 54:1037-1048.

Lee, I. M., Gundersen-Rindal, D. E., Davis, R. E., and Bartoszyk, I. M. 1998. Revised classification scheme of phytoplasmas based on RFLP analyses of 16S rRNA and ribosomal protein gene sequences. Int. J. Syst. Bacteriol. 48: 1153-1169.

Martini, M., Delić, D., Liefting, L., and Montano, H. 2018. Phytoplasmas infecting vegetable, pulse and oil crops. Pages 31-65 in: Phytoplasmas: Plant Pathogenic Bacteria - I. G. P. Rao, A. Bertaccini, N. Fiore, and L. W. Liefting, eds. Springer, Singapore.

Martini, M., Lee, I., Bottner, K., Zhao, Y., Botti, S., Bertaccini, A., Harrison, N., Carraro, L., Marcone, C., Khan, A., and Osler, R. 2007. Ribosomal protein gene-based phylogeny for finer differentiation and classification of phytoplasmas. Int. J. Syst. Evol. Microbiol. 57: 2037-2051

Murray, M. G., and Thompson, W. F. 1980. Rapid isolation of high molecular weight plant DNA. Nucleic Acids Res. 8:4321-4326.

Olivier, C., Dumonceaux, T., Pérez-López, E., Wist, T., Elliot, B., and Vail, S. 2017. Detection, symptomatology and management of aster yellows disease in canola. Pages 233-246 in: Integrated Management of Insect Pests on Canola and Other Brassica Oilseed Crops. G. V. P. Reddy, ed. CAB International, Wallingford, U.K.

Pérez-López, E., Olivier, C. Y., Luna-Rodríguez, M., Rodríguez, Y., Iglesias, L. G., Castro-Luna, A., Adame-García, J., and Dumonceaux, T. J. 2016. Maize bushy stunt phytoplasma affects native corn at high elevations in southeast Mexico. Eur. J. Plant Pathol. 145:963-971.

Pérez-López, E., Rodríguez-Martínez, D., Olivier, C. Y., Luna-Rodríguez, M., and Dumonceaux, T. J. 2017. Molecular diagnostic assays based on cpn60 UT sequences reveal the geographic distribution of subgroup 16SrXIII-(A/I)I phytoplasma in Mexico. Sci. Rep. 7:950.

Ratnasingham, S., and Hebert, P. D. N. 2007. BOLD: The Barcode of Life Data System (http://www.barcodinglife.org). Mol. Ecol. Notes 7:355-364.

Ratnasingham, S., and Hebert, P. D. N. 2013. A DNA-based registry for all animal species: The barcode index number (BIN) system. PLoS One 8: e66213.

Smieja, M., Mahony, J. B., Goldsmith, C. H., Chong, S., Petrich, A., and Chernesky, M. 2001. Replicate PCR testing and probit analysis for detection and quantitation of Chlamydia pneumoniae in clinical specimens. J. Clin. Microbiol. 39:1796-1801.

Tanne, E., Boudon-Padieu, E., Clair, D., Davidovich, M., Melamed, S., and Klein, M. 2001. Detection of phytoplasma by polymerase chain reaction of insect feeding medium and its use in determining vectoring ability. Phytopathology 91:741-746. 